To Maega | Jurnal Pengabdian Masyarakat

Oktober-2021, Vol.4, No.3, hal 316-330

$\operatorname{ISSN}(P): 2622-6332 ; \operatorname{ISSN}(E): 2622-6340$

http://www.ojs.unanda.ac.id/index.php/tomaega

\title{
Pemberdayaan Ibu-Ibu Posyandu Sentolo Lor Melalui Edukasi Bahaya Pembalut dan Ecoliteracy: Upaya Preventif Permasalahan Kesehatan Reproduksi \& Lingkungan
}

\author{
Anindita Imam Basri ${ }^{1}$, Siti Nur Utaminingsih ${ }^{1}$, Valsa Ayunda Tisya ${ }^{*}$ \\ ${ }^{1}$ Program Studi Manajemen, Fakultas Bisnis, Universitas PGRI Yogyakarta \\ *Correspondent Email: valsayundatisya@gmail.com
}

\author{
Article History:
}

Received: 08-09-2021; Received in Revised: 22-09-2021; Accepted: 10-10-2021

DOI: http://dx.doi.org/10.35914/tomaega.v4i3.851

\begin{abstract}
Abstrak
Pembalut merupakan kebutuhan primer bagi setiap perempuan yang telah mengalami masa pubertas. Namun, banyak kalangan wanita yang tidak terlalu memperdulikan personal hygiene pada saat penggunaan pembalut sekali pakai, sehingga berisiko terhadap kesehatan organ reproduksi. Berdasarkan hasil observasi di Dusun Sentolo Lor, Kecamatan Sentolo, Kabupaten Kulon Progo, Provinsi Daerah Istimewa Yogyakarta. masih banyak remaja dan ibu-ibu yang utamanya belum mengetahui dan memahami bahaya pemakaian pembalut sekali pakai. Kegiatan ini bertujuan untuk menumbuhkan kesadaran bahaya pembalut sekali pakai, cara menjaga personal hygiene, dan mengajak mitra untuk beralih ke pembalut ramah lingkungan. Metode pelaksanaan yang digunakan yaitu penyuluhan (ceramah), diskusi, tanya jawab, serta evaluasi program. Hasil evaluasi program menunjukkan adanya peningkatan signifikan dari setiap indikator setelah edukasi dilaksanakan. Dengan demikian, kegiatan pengabdian ini telah berhasil meningkatkan kualitas sumber daya manusia di Dusun Sentolo Lor.
\end{abstract}

Kata Kunci: Pemberdayaan, Posyandu, Pembalut, Personal Hygiene.

\begin{abstract}
Sanitary napkins are a primary need for every woman who has experienced puberty. However, many women do not really care about personal hygiene when using disposable sanitary napkins, so it poses a risk to the health of the reproductive organs. Based on the results of observations in Sentolo Lor Hamlet, Sentolo District, Kulon Progo Regency, Yogyakarta Special Region Province. there are still many teenagers and mothers who mainly do not know and understand the dangers of using disposable sanitary napkins. This activity aims to raise awareness of the dangers of single-use sanitary napkins, how to maintain personal hygiene, and invite partners to switch to environmentally friendly sanitary napkins. The implementation method used is counseling (lecture), discussion, question and answer, and program evaluation. The results of the program evaluation showed a significant increase in each indicator after the education was implemented. Thus, this service activity has succeeded in improving the quality of human resources in Dusun Sentolo Lor.
\end{abstract}

Key Word: Empowerment, Posyandu, Sanitary Napkins, Personal Hygiene. 


\section{Pendahuluan}

Hasil data Berita Resmi Statistik No.07/01/Th. XXIV menunjukkan total penduduk Indonesia secara keseluruhan mencapai 270,20 juta penduduk per 21 Januari 2021. Provinsi Daerah Istimewa Yogyakarta (DIY) merupakan salah satu wilayah padat penduduk yang memiliki jumlah penduduk perempuan yang lebih besar dibandingkan jumlah penduduk laki-laki. Data statistik resmi menunjukkan bahwa dalam kurun waktu tiga tahun terakhir, kuantitas penduduk perempuan mengalami eskalasi setiap tahunnya. Jumlah penduduk perempuan di DIY pada tahun 2018 terhitung sebesar 1931 ribu jiwa, lalu pada tahun 2019 meningkat menjadi 1957,3 ribu jiwa, hingga mencapai angka 1983,8 ribu jiwa pada tahun 2020. Angka-angka tersebut jauh lebih besar dibandingkan jumlah penduduk lakilai yang hanya sebesar 1887,3 ribu jiwa di tahun 2018, kemudian di tahun 2019 sebesar 1911,3 ribu jiwa, dan tahun 2020 tercatat sebesar 1935,4 ribu jiwa (Badan Pusat Statistik, 2021). Data aktual tersebut menunjukkan bahwa kaum perempuan mendominasi jumlah penduduk yang ada di wilayah Daerah Istimewa Yogyakarta. Selain tinjauan demografi, hal penting yang perlu disoroti adalah semakin tinggi jumlah penduduk, maka akan semakin tinggi aspek dan tingkat kebutuhan masyarakat yang perlu diperhatikan.

Aspek kesehatan merupakan aspek kehidupan yang terpenting bagi setiap manusia. Kualitas kesehatan masyarakat dari berbagai subjek sangat penting untuk diperhatikan dan diberdayakan secara berkesinambungan. Dalam ruang lingkup masyarakat, subjek yang paling banyak diperhatikan adalah ibu hamil dan menyusui, bayi, anak-anak, dan lansia. Berkaitan dengan beberapa subjek utama tersebut, terdapat beberapa kegiatan pengabdian masyarakat dalam bidang kesehatan yang telah dilakukan para pengabdi sebelumnya seperti sebagai berikut. Nur dkk. (2021) telah melakukan upaya peningkatan gizi balita di Kupang dengan melalui pelatihan cara pembuatan pangan lokal yang kaya protein. Siahaan dkk. (2021) memberikan penyuluhan gizi seimbang dan cuci tangan kepada siswa sekolah dasar dengan disertai metode mini game. Selain itu, Ristanti \& Masita (2021) melakukan seminar daring dan pelatihan pemberian ASI kepada kader dan ibu postpartum. Rosyida dkk., (2021) juga telah merealisasikan pengabdian masyarakat dengan memberikan penyuluhan dan pelatihan pembuatan PMT (Pemberian Makanan Tambahan) bagi ibu-ibu PKK untuk meningkatkan gizi anak. Di samping itu, Ariyanti dkk., (2020) melakukan program pemberdayaan kader sebagai upaya preventif dan antisipasi penyait hipertensi bagi lansia.

Bertolak dari kompleksitas kebutuhan ataupun permasalahan kesehatan di berbagai subjek masyarakat tersebut, kalangan remaja juga sangat memerlukan perhatian khusus, khususnya bagi kaum wanita. Hal ini dikarenakan wanita memiliki proses maturitas yang berbeda secara biologis dengan kaum laki-laki. Personal hygiene merupakan salah satu aspek kesehatan yang vital bagi setiap wanita, terutama pada masa wanita mengalami menstruasi, sehingga personal 
hygiene saat menstruasi sangat memerlukan pengetahuan dan sikap yang tepat. Menstruasi adalah peluruhan bagian dalam dinding rahim atau endometrium wanita (Pristya \& Amalia, 2021). Personal hygiene pada saat menstruasi merupakan suatu upaya untuk menjaga kebersihan dan kesehatan organ intim wanita semasa menstruasi serta berperan vital dalam kesehatan, terutama sebagai pencegahan infeksi atau penyakit organ reproduksi wanita (Phonna dkk., 2018). Pembalut wanita merupakan kebutuhan primer wanita pada masa menstruasi yang biasanya terjadi setiap bulan (Zamani dkk., 2012) dan berfungsi sebagai penampung darah menstruasi. Untuk menjaga kualitas personal hygiene saat menstruasi, maka hal lain yang perlu dipertimbangkan adalah pemilihan dan penggunaan pembalut.

Hingga kini, telah marak berbagai macam produk pembalut sekali pakai yang terkesan lebih praktis (Ardiyanti \& Pramitasari, 2019) dengan harga jual yang terjangkau. Tak heran apabila pembalut sekali pakai menjadi kebutuhan primer bagi setiap wanita dan jumlah produksi pembalut meningkat semakin meningkat. Mayoritas masyarakat pada dasarnya belum mengetahui adanya solusi altrenatif selain pembalut sekali pakai, yaitu pembalut kain. Pembalut kain dinilai dan diyakini lebih aman bagi kaum wanita, karena tidak mengandung zat-zat kimia berbahaya yang dapat mengancam kesehatan organ reproduksi wanita. Hal ini dikarenakan gel yang terdapat dalam pembalut sekali pakai tidak terjamin keamanannya untuk kesehatan organ reproduksi. Kapas yang digunakan sebagai isi pembalut bukan sepenuhnya kapas asli, namun dapat berupa campuran serbuk kayu dan kertas bekas yang telah ditambahkan pewangi dan pemutih yang dapat menyebabkan risiko kanker rahim (Zamani dkk., 2012). Selain itu, banyak kasus produsen yang mendaur ulang kertas bekas untuk memproduksi pembalut dengan proses bleaching (memutihkan), pemberian wewangian, dan sterilisasi.

Di Indonesia, faktor utama yang menyebabkan kanker serviks adalah kualitas pembalut yang buruk. Indonesia juga merupakan negara yang menduduki kasus kanker serviks peringkat satu di dunia dan hal ini disebabkan oleh faktor rendahnya kualitas pembalut sebesar 62\% (Susanti \& Wijaya, 2018). Pembalut sekali pakai mengandung zat dioxin yang sangat membahayakan kesehatan tubuh, khususnya organ reproduksi wanita. Implikasi negatif yang ditimbulkan yaitu kanker serviks atau leher rahim, endometiosis (penebalan dinding rahim), vaginitis atau infeksi vagina, sulit memiliki keturunan, keputihan, tumor organ reproduksi, haid tidak teratur dan PMS atau pre menstruation syndrome (Julina, 2012). Zat berbahaya lainnya bagi reproduksi wanita yaitu zat Dioxin dengan salah satu senyawa Klorin $\left(\mathrm{Cl}_{2}\right)$ yang berbahaya dan justru biasanya digunakan sebagai pemutih pembalut. Kandungan senyawa Klorin ini sangat berbahaya bagi kesehatan reproduksi wanita karena dapat menyebabkan iritasi, gatal-gatal, keputihan, bahkan kanker (Nasution dkk., 2012).

Di samping itu, klorin juga dapat mempengaruhi sistem kekebalan tubuh, pencernaan, hati dan ginjal, serta gangguan pada sistem saraf (neurological) (C)To Maega / Jurnal Pengabdian Masyarakat. This is an open access article under the CC BY-SA 4.0 license (https://creativecommons.org/licenses/by-sa/4.0/). 
(Hasan, 2006). Riyana Kadarsari selaku Dokter Spesialis Obstetri Ginekologi, mengatakan bahwa pembalut tidak hanya mengandung zat dioxin, melainkan juga terdapat residu pupuk, pestisia, serta furan. Di samping itu, Women's Voices For The Health melaporkan bahwa pembalut juga mengandung empat zat kimiawi yang berbahaya, yaitu acetone yang memicu iritasi, styrene yang memicu kanker, Chloromethane yang memicu gangguan syaraf dan reproduksi), dan Chloroethane yang memicu gangguan kanker dan otot (Salsabila, 2019).

Tidak hanya berdampak pada aspek kesehatan, namun pembalut sekali pakai juga berdampak negatif terhadap lingkungan. Tingginya implikasi negatif dari penggunaan pembalut sekali pakai terhadap lingkungan sangat relevan dengan fenomena yang ada di masyarakat, yaitu sebagian masyarakat yang masih tidak terlalu peduli mengenai pencemaran lingkungan dan efek negatif lainnya. Banyak masyarakat yang hanya membuang sampah pembalut sembarangan ke sungai. Tak heran apabila pembalut menjadi salah satu penyumbang banyaknya sampah plastik di Indonesia. Terlebih lagi, pembalut sekali pakai bersifat unbiodegradable (tidak mudah terurai). Terdapat sekitar 1,4 milyar sampah pembalut sekali pakai yang dihasilkan setiap bulannya. Selain itu, kebiasan buruk sebagian masyarakat Indonesia, yaitu kebiasaan membakar sampah yang di dalamnya terdapat sampah pembalut. Apabila sampah pembalut terbakar, maka kandungan plastik di dalam pembalut apabila terbakar suhu $<800^{\circ} \mathrm{C}$, maka dioxin yang telah mengenai tumbuhan dapat termakan manusia (Zamani dkk., 2012).

Kesimpulan dari pemarapan di atas adalah penggunaan pembalut sekali pakai pada realitanya memberikan sejumlah dampak negatif terhadap kesehatan dan lingkungan. Namun, masih banyak kaum wanita yang belum mengetahui dan memahami pentingnya menjaga kesehatan reproduksi. Dominan wanita lebih menyukai sesuatu hal yang praktis, namun tidak mempedulikan akibat atau bahaya dari penggunaan pembalut sekali pakai. Golongan wanita memilih pembalut sekali pakai karena sangat mudah di temui di berbagai toko ataupun pusat perbelanjaan dan praktis. Oleh karena itu, sangat penting untuk memberdayakan kaum wanita dengan memberikan edukasi tentang menstruasi untuk mereduksi permasalahan infeksi organ reproduksi sebagian besar kalangan wanita di setiap penjuru dunia (Karout, 2015), khususnya di Indonesia. Wilayah pedesaan patut dijadikan target pengabdian masyarakat karena mayoritas masih memiliki tingkat pengetahuan ataupun pendidikan yang rendah. Sehingga edukasi dalam bidang ini sangat cocok untuk lebih diprioritaskan kepada target di wilayah pedesaan.

Hal ini relevan dengan kondisi aktual yang ada di Dusun Sentolo Lor, Kecamatan Sentolo, Kabupaten Kulon Progo, Provinsi Daerah Istimewa Yogyakarta. Letak wilayah Padukuha Sentolo Lor lokasinya di sebelah barat rel kereta api yang berada di Jl. Raya Wates Km 16 Sentolo, Kulon Progo. Luas wilayah dusun Sentolo Lor $95.900 \mathrm{~m} 2$ yang terbagi menjadi beberapa bagian seperti persawahan, pekarangan, pemakaman, jalan dan lainnya. Dusun ini terbagi (O)To Maega / Jurnal Pengabdian Masyarakat. This is an open access article under the CC BY-SA 4.0 license (https://creativecommons.org/licenses/by-sa/4.0/). 
menjadi 6 rukun tetangga (RT) dan 3 rukun warga (RW). Hasil observasi lapangan dan wawancara dengan perkumpulan ibu-ibu posyandu Dusun Sentolo Lor menunjukkan sejumlah permasalahan mitra, yaitu antara lain: 1) Mayoritas kaum wanita yang ada di Dusun Sentolo Lor memiliki keterbatasan pengetahuan mengenai peran penting personal hygiene ataupun kesehatan reproduksi, 2) Banyak kaum wanita Dusun Sentolo Lor yang tidak mengetahui bahan berbahaya dari pembalut sekali pakai, 3) Minimnya pengetahuan tentang berbagai dampak negatif dari penggunaan pembalut sekali pakai, 4) Banyak yang belum mengetahui alternatif produk pengganti pembalut sekali pakai. 5) Rendahnya program pemberdayaan kaum wanita dalam bidang kesehatan, khususnya mengenai kesehatan reproduksi wanita. Oleh karena itu, solusi yang ditawarkan adalah pengadaan sosialisasi terkait bahaya pembalut sekali pakai dan edukasi mengenai ecoliteracy sebagai solusi alternatif dmpak negatif pembalut sekali pakai bagi lingkungan. Sasaran dari kegiataan pengabdian masyarakat ini ditujukan kepada perkumpulan ibu-ibu posyandu Dusun Sentolo Lor.

Adapun tujuan dari realisasi pengabdian kepada masyarakat ini, yaitu: 1) Memberikan pengetahuan tentang bahan-bahan berbahaya yang terkandung dalam pembalut sekali pakai, 2) Memberikan pengetahuan dan pemahaman kepada ibuibu posyandu Dusun Sentolo Lor bahwa terdapat bahaya pemakaian pembalut sekali pakai memiliki berbagai dampak negatif, 3) Memberikan pengetahuan dan pemahaman bahwa terdapat solusi alternative dari penggunaan pembalut sekali pakai. Di samping itu, manfaat yang diharapkan, yaitu: 1) Meningkatkan kualitas kesehatan para kaum wanita, 2) Meningkatkan pengetahuan dan pemahaman mengenai bahaya penggunaan pebalut sekali pakai beserta solusinya, 3) Menumbuhkan kesadaran dan inisiatif bagi kaum wanita untuk menerapkan pola hidup sehat.

\section{Metode}

Kegiatan pengabdian masyarakat dilakukan di Dusun Sentolo Lor, Kecamatan Sentolo, Kabupaten Kulon Progo, Provinsi Daerah Istimewa Yogyakarta pada tanggal 12 Februari 2021, dengan sasaran kalangan ibu-ibu posyandu ini. Pemilihan subjek pengabdian ini dianggap snagat cocok karena selain bertujuan meningatkan kualitas kesehatan reproduksi bagi kalangan ibu-ibu, namun dari para peserta ibu-ibu tersebut juga dapat mentransferkan berbagai pengetahuan dan wawasan yang telah diperoleh setelah sosialiasi kepada para putrinya. Dengan kata lain, program pemberdayaan wanita ini juga dapat meningkatkan kualitas kesehatan reproduksi para remaja putri ataupun yang sudah beranjak dewasa. Selain itu, kegiatan pengabdian masyarakat ini juga telah melalui skema pelaksanaan kegiatan mulai dari observasi hingga penentuan target luaran yang ingin dicapai, seperti pada bagan pada gambar 1 . 


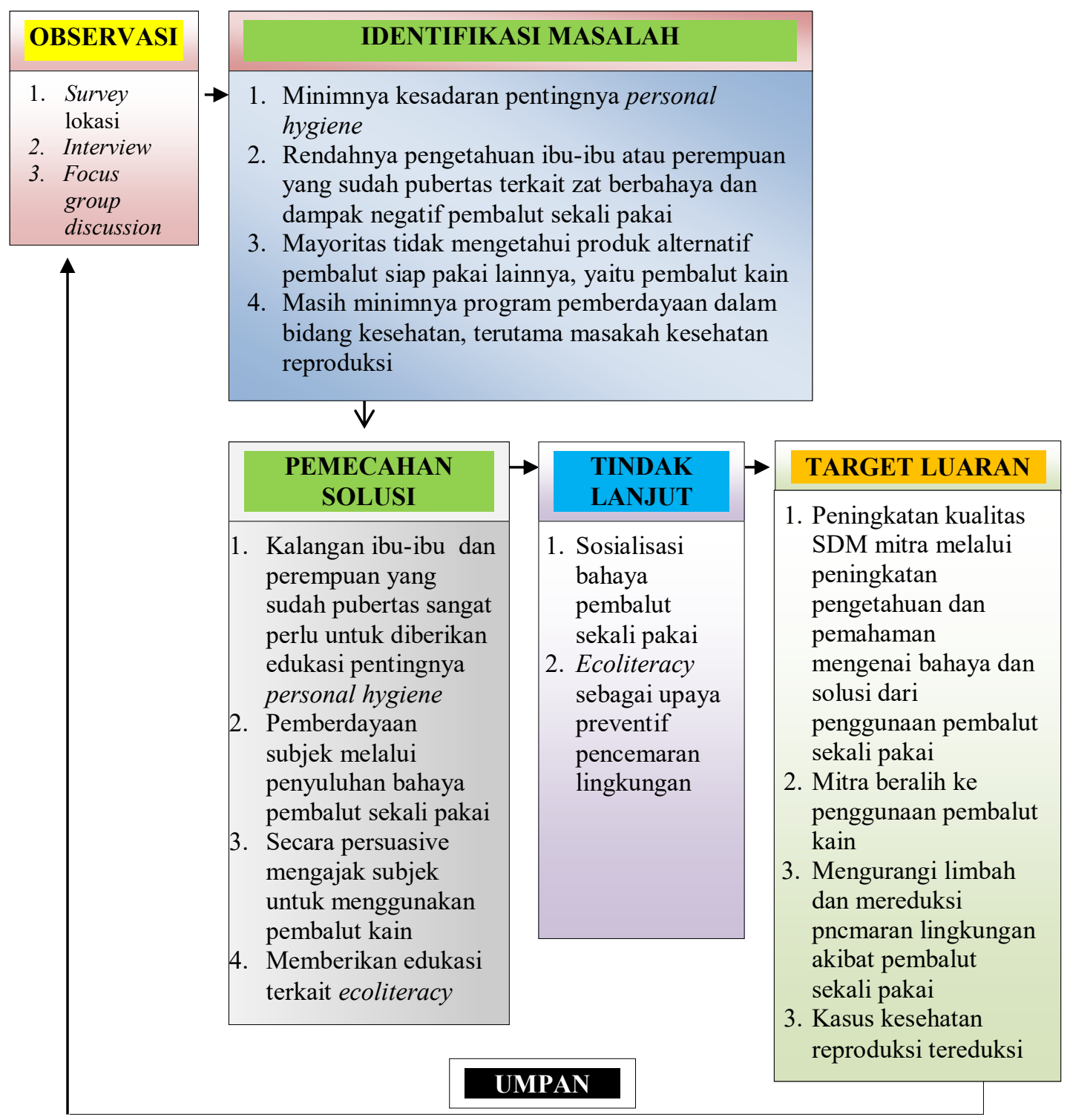

Gambar 1. Skema Konseptual Kegiatan Pengabdian Masyarakat

Program pengabdian ini juga bertumpu pada beberapa alur tahapan, yaitu tahap persiapan, pelaksanaan, evaluasi program, dan pelaporan. Secara ringkas, tahapan kegiatan program pengabdian masyarakat ini disajikan dalam Tabel 1 sebagai berikut.

Tabel 1. Tahap Kegiatan Program Pengabdian kepada Masyarakat

\section{Tahap Persiapan}

Pra-Survei

Mengidentifikasi dan menganalisis situasi berupa

permasalahan dan kebutuhan mitra

Pembentukan Tim

Tim PKM ditujukan untuk menemukan solusi dan

PKM

tindak lanjut dari analisis situasi mitra

Pembuatan Proposal

Penyusunan proposal sebagai tindak lanjut dari perencanaan kegiatan pngabdian yang menjwab 


\begin{tabular}{|c|c|}
\hline \multirow{2}{*}{$\begin{array}{l}\text { Rapat Koordinasi } \\
\text { Penyusunan Bahan } \\
\quad \text { Sosialisasi }\end{array}$} & $\begin{array}{l}\text { lahan mitra dan media penyediaan dana dalam } \\
\text { solusi pelaksanaan bagi mitra } \\
\text { cang perencanaan program secara konseptual, } \\
\text { operasional, dan tugas dari tim \& mitra }\end{array}$ \\
\hline & Pembuatan materi kegiatan \\
\hline \multicolumn{2}{|c|}{$\begin{array}{c}\text { Tahap Pelaksanaan } \\
\text { (Kegiatan Dilaksanakan di Lokasi Mitra) }\end{array}$} \\
\hline Sosialisasi & $\begin{array}{l}\text { Kegiatan dilaksanakan melalui ceramah dan } \\
\text { penyampaian materi (45 menit) }\end{array}$ \\
\hline Tanya Jawab dan diskusi & Tanya jawab dan diskusi (15 menit) \\
\hline \multicolumn{2}{|c|}{ Tahap Evaluasi Program } \\
\hline \multicolumn{2}{|c|}{$\begin{array}{l}\text { Evaluasi program merupakan upaya pengabdi dengan melakukan perbandingan } \\
\text { tingkat pengetahuan mitra antara sebelum dan setelah program terlaksana. Pre- } \\
\text { test diadakan sebelum sosialisasi (15 menit) dan pra-test dilakukan setelah } \\
\text { sosialisasi (15 menit) }\end{array}$} \\
\hline \multicolumn{2}{|c|}{ Tahap Pelaporan } \\
\hline $\begin{array}{r}\text { Penyusunan laporan dil } \\
\text { pelaksanaan pro }\end{array}$ & $\begin{array}{l}\text { in sebagai bentuk pertanggung jawaban atas } \\
\text { untuk kemudian dilakukan publikasi }\end{array}$ \\
\hline
\end{tabular}

Metode yang dilakukan dalam kegiatan pengabdian masyarakat ini, yaitu pendidikan masyarakat. Edukasi ini direalisasikan dalam bentuk penyuluhan atau sosialisasi mengenai bahaya pembalut sekali pakai, cara menjaga personal hygiene, dan memberikan solusi alternatif dibandingkan pembalut sekali pakai, yaitu popok kain. Selain itu, solusi kedua meliputi edukasi mengenai ecoliteracy untuk meningkatkan kesadaran bahwa pembalut sekali pakai sangat berpotensial dalam pencemaran lingkungan, Melalui pendidikan yang ditransfer kepada masyarakat diharapkan dapat menjadi stimulus dan penggerak sikap positif yang akan mulai membentuk kesadaran dan perilaku hidup sehat yang berkualitas bagi masyarakat, khususnya kalangan wanita yang ada di Dusun Sentolo Lor. Metode yang kedua adalah konsultasi. Pengabdi memberikan media dan sarana konsultasi bagi ibu-ibu posyandu Dusun Sentolo Lor, baik secara offline maupun online. Secara implisit, metode ini juga dapat berperan sebagai monitoring dan evaluasi, sehingga tim pengabdi dapat tetap memberikan pendampingan melalui konsultasi tersebut. Berikut merupakan metode pengabdian dalam hal alur tahapan yang ditempuh pengabdi dalam pelaksanaan kegiatan masyarakat ini.

\section{Tahap Persiapan}

Secara lebih detailnya, tahapan persiapan kegiatan pengabdian masyarakat ini, meliputi: 1) Identifikasi permasalahan Dusun Sentolo Lor secara keseluruhan, 2) Identifikasi prioritas permasalahan mitra, 3) Identifikasi solusi relevan yang didasarkan hasil pertimbangan identifikasi permasalahan desa dan identifikasi permasalahan mitra. Hal ini ditujukan untuk mendapatkan solusi yang sesuai dengan permasalahan ataupun kebutuhan mitra. Hasil identifikasi permasalahan mitra pada akhirnya terkonsentris terhadap pentingnya edukasi dengan objek yaitu 
bahaya penggunaan pembalut sekali pakai yang diikuti penyampaian berbagai pengetahuan dan wawasan relevan lainnya.

\section{Tahap Pelaksanaan}

Untuk tahap pelaksanaan, pelaksanaan kegiatan pengabdian masyarakat ini dilakukan dengan menggunakan beberapa metode, yaitu: 1) Penyuluhan atau ceramah yang ditujukan untuk mentransferkan berbagai ilmu dan wawasan mengenai bahaya pembalut sekali pakai. 2) Diskusi dengan ibu-ibu posyandu 3) Tanya jawab ditujukan agar peserta dapat menanyakan berbagai hal relevan yang membutuhkan konfirmasi kebenaran ataupun sebagai media konsultasi peserta.

\section{Tahap Evaluasi Program}

Demi mengukur tingkat keberhasilan program pemberdayaan masyarakat ini, kegiatan pengabdian masyarakat akan ditinjau melalui tahap evaluasi program, yaitu observasi dan wawancara. Evaluasi ini direalisasikan melalui perbandingan kondisi mitra sebelum dan setelah program dilaksanakan. Indikator keberhasilan dalam pelaksanaan kegiatan pengabdian masyarakat ini, yaitu adanya peningkatan persentase pengetahuan dan pemahaman di setiap indikator minimal $30 \%$. Nilai persentase evaluasi program dihitung berdasarkan jumlah peserta (n).

\section{Tahap Pelaporan}

Setelah melakukan tahap evaluasi program, tahap selanjutnya adalah tahap pelaporan sebagai bentuk pertanggungjawaban pelaksanaan program pemberdayaan masyarakat.

\section{Hasil dan Pembahasan}

Kegiatan pengabdian masyarakat dilakukan di Dusun Sentolo Lor, Kecamatan Sentolo, Kabupaten Kulon Progo, Propinsi Daerah Istimewa Yogyakarta, dengan target atau sasaran pengabdian yaitu ibu-ibu posyandu Dusun Sentolo Lor berjumlah 10 peserta. Keterbatasan peserta dikarenakan kondisi pandemic Covid-19, tim pengabdi tidak bisa mengadakan kegiatan dengan jumlah peserta tidak lebih dari sepuluh orang. Hal ini ditujukan untuk menghindari kerumunan yang dapat menyebabkan kemungkinan penyebaran Covid-19. Program realisasi pengabdian masyarakat ini dilaksanakan di Rumah Bapak Dukuh Sentolo Lor, pada tanggal 12 Februari 2021 pukul 10.00 WIB. Jumlah peserta yang hadir yaitu sebanyak 10 peserta ibu-ibu posyandu dusun Sentolo Lor.

Secara keseluruhan, realisasi program pengabdian masyarakat telah terlaksana dengan baik dan tanpa hambatan yang berarti. Kegiatan dilakukan dengan durasi sembilan puluh (90) menit. Sebelum dimulai, para peserta diberikan kuesioner. Kemudian kegiatan dimulai dengan pemaparan materi. Para peserta sangat memahami dan serius dalam menyimak setiap materi yang disampaikan. Setelah sesi penyampaian materi, dilakukan sesi tanya jawab dan diskusi. Para peserta sangat antusias dan semangat untuk memberikan pertanyaan-pertanyaan terkait dengan bahaya pembalut sekali pakai. 
[ 324 ] Anindita Imam Basri, dkk / To Maega : Jurnal Pengabdian Masyarakat, Vol.4; No.3; Oktober, 2021

Hasil keluaran yang dihasilkan dari realisasi program pengabdian masyarakat ini meliputi sekumpulan data nilai persentase tingkat pencapaian target luaran untuk setiap indikator, serta hasil tersebut dilakukan perbandingan antara kondisi mitra sebelum dan sesudah sosialisasi, serta meninjau tingkat keberhasilan program pengabdian dalam menjawab permasalahan maupun kebutuhan mitra. Berikut hasil pencapaian target luaran sosialisasi yang tersajikan dalam tabel 2.

Tabel 2. Hasil Pencapaian Sosialisasi

\begin{tabular}{|c|c|c|c|c|c|}
\hline \multirow{2}{*}{ No. } & \multirow{2}{*}{ Indikator } & \multicolumn{2}{|c|}{ Pre-test } & \multicolumn{2}{|c|}{ Pra-test } \\
\hline & & $\mathrm{n}$ & $\%$ & n & $\%$ \\
\hline 1. & $\begin{array}{l}\text { Pemahaman mengenai bahan berbahaya dari } \\
\text { pembalut sekali pakai }\end{array}$ & 1 & $10 \%$ & 9 & $90 \%$ \\
\hline 2. & $\begin{array}{l}\text { Pemahaman mengenai dampak negatif pembalut } \\
\text { sekali pakai dari segi kesehatan }\end{array}$ & 2 & $20 \%$ & 10 & $100 \%$ \\
\hline 3. & $\begin{array}{l}\text { Pemahaman mengenai dampak negatif dari } \\
\text { penggunaan pembalut sekali pakai dari segi } \\
\text { lingkungan }\end{array}$ & 4 & $40 \%$ & 10 & $100 \%$ \\
\hline 4. & $\begin{array}{l}\text { Pemahaman mengenai pembalut ramah } \\
\text { lingkungan }\end{array}$ & 3 & $30 \%$ & 10 & $100 \%$ \\
\hline 5, & $\begin{array}{l}\text { Pemahaman mengenai perbedaan pembalut sekali } \\
\text { pakai dengan pembalut kain }\end{array}$ & 4 & $40 \%$ & 10 & $100 \%$ \\
\hline
\end{tabular}

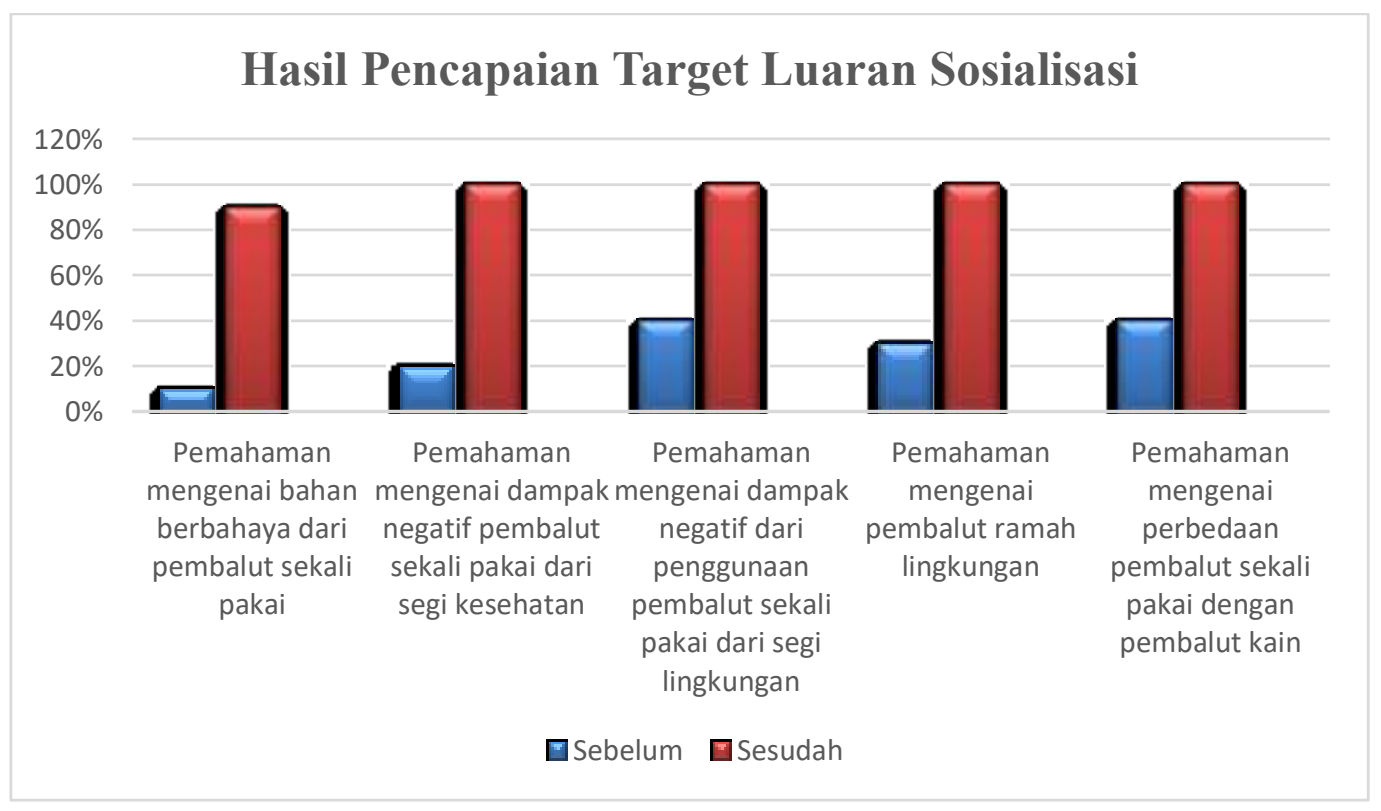

Gambar 2. Grafik Hasil Pencapaian Target Luaran Sosialisasi

Berdasarkan hasil observasi dan wawancara kepada ibu-ibu Posyandu Dusun Sentolo Lor terkait bahan pembalut sekali pakai, hasil yang diperoleh 
adalah hanya $10 \%$ atau satu peserta yang mengetahui bahan-bahan berbahaya yang terkandung dalam pembalut sekali pakai. Zat klorin, dioxin, furan, acetone, stryrene, chloroethane, chloromethane, phthalates, dan chlorin merupakan zat-zat kimia berbahaya yang terdapat dalam pembalut sekali pakai (Sasetyaningtyas, 2018). Hal tersebut menunjukkan bahwa tingkat pengetahuan ibu-ibu posyandu Dusun Sentolo Lor terkait bahaya pembalut sekali pakai masih sangat rendah. Namun, setelah diadakanya sosialisasi, hampir seluruh peserta atau $90 \%$ peserta dapat mengetahui bahan-bahan berbahaya yang terkandung dalam pembalut sekali pakai.

Pada saat pengabdi menciptakan komunikasi yang interaktif, terdapat peserta yang mengakui tidak mengetahui sama sekali terkait bahan-bahan berbahaya apa saja yang terkandung di dalam pembalut sekali pakai. Alasan memilih pembalut sekali pakai dikarenakan praktis dan mudah didapatkan. Selain itu, interaksi yang baik selama kegiatan sosialisasi berlangsung dibuktikkan dengan adanya pertanyaan dan respon yang aktif dari para peserta. Hal ini dikarenakan beberapa peserta menanyakan terkait kebenaran zat-zat berbahaya dalam pembalut sekali pakai, sebab merasa bahwa pembalut tidak memberikan efek samping yang buruk selama ini. Pengabdi menjawab bahwa bahaya pembalut sekali pakai pada dasarnya bisa diketahui secara jelas melalui uji klinik kesehatan, karena menyangkut organ dalam manusia. Wanita bisa saja belum merasakan gejala-gejala permasalahan organ reproduksi, namun zat kimia pembalut sekali pakai kemungkinan besar akan tetap memberikan efek secara biologis meskipun tidak disadari.

Setelah itu, pemaparan materi kedua dilanjutkan. Selain itu, sebelum sosialisasi hanya sebesar $20 \%$ peserta yang mampu mengetahui dampak negatif pembalut sekali pakai dari segi kesehatan. Persentase ini menunjukkan rendahnya pengetahuan ibu-ibu posyandu Dusun Sentolo Lor mengenai bahaya penggunaan pembalut sekali pakai bagi kesehatan. Kanker serviks atau leher rahim, endometiosis (penebalan dinding rahim), vaginitis atau infeksi vagina, sulit memiliki keturunan, keputihan, tumor organ reproduksi, haid tidak teratur dan PMS atau pre menstruation syndrome, gangguan sistem kekebalan tubuh, pencernaan, hati dan ginjal, serta gangguan pada sistem saraf, merupakan sejumlah penyakit atau gangguan kesehatan yang diakibatkan oleh pembalut sekali pakai (Hasan, 2006).

Untuk memahami materi ini dengan lebih mudah, peserta diberikan pemahaman bahwa efek negatif pembalut sekali pakai biasanya ditandai dengan keputihan yang tidak sehat. Adanya keputihan ini disebabkan karena kondisi kelembapan area genital wanita yang tertutupi pembalut dan diperparah dengan kondisi pembalut yang biasanya tidak segera diganti, sehingga menyebabkan munculnya berbagai bakteri atau jamur. Selain itu, pemateri juga turut menjelaskan kasus permasalahan kesehatan reproduksi kedua yang sering dialami oleh kalangan wanita, yaitu kanker rahim. Hal in menunjukkan bahwa CTo Maega / Jurnal Pengabdian Masyarakat. This is an open access article under the CC BY-SA 4.0 license (https://creativecommons.org/licenses/by-sa/4.0/). 
penggunaan pembalut sekali pakai tidak dapat disepelekan, karena dapat menyebabkan berbagai penyakit serius. Para peserta sangat menyimak dengan baik pada saat diberikan berbagai wawasan dan edukasi tersebut. Setelah sosialisasi, pengetahuan peserta terkait bahaya pembalut sekali pakai bagi kesehatan telah berhasil meningkat sebesar $100 \%$.

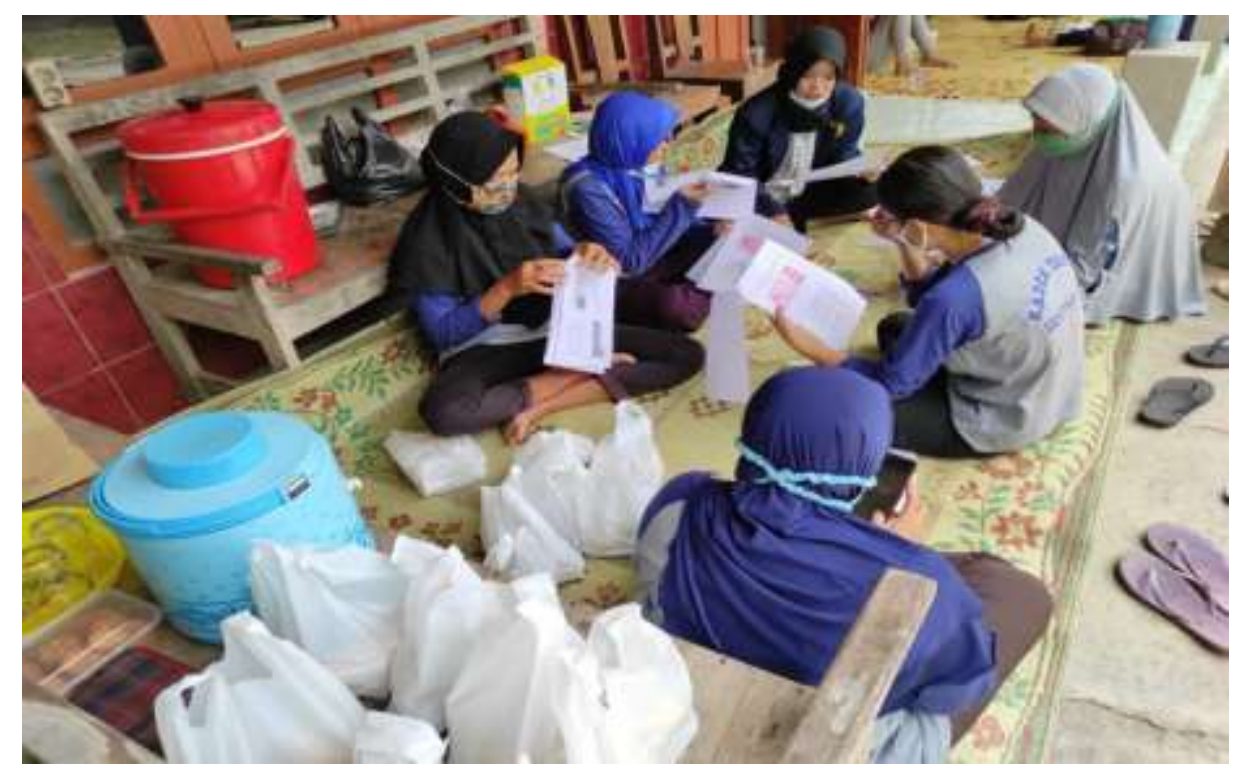

Gambar 3. Pelaksanaan Kegiatan Sosialisasi Bersama Ibu-ibu Posyandu Sentolo

Lor

Berkaitan dengan indikator ketiga, hasil observasi sebelum sosialisasi menunjukkan bahwa hanya sebesar $40 \%$ peserta yang mengetahui dampak negatif pembalut sekali pakai dari segi lingkungan. Hal ini mengindikasikan bahwa banyak ibu-ibu Dusun Sentolo Lor yang kurang mengetahui bahwa pembalut sekali pakai sampah menyumbang sampah terbanyak dan mencemari lingkungan karena sampah pembalut sangat sulit terurai. Menurut Sasetyaningtyas (2018), satu sampah pembalut sekali pakai sama dengan empat kantong plastik. Artinya bahwa satu pembalut yang digunakan wanita akan sama dengan 40.000-60.000 tas plastik yang dibuang. Para peserta diberikan pemahaman bahwa limbah pembalut sekali pakai akan sangat mencemari lingkungan, terutama ekosistem sungai yang tentunya akan Setelah sosialisasi, seluruh peserta atau $100 \%$ peserta telah memahami bahaya pembalut sekali pakai bagi lingkungan.

Di samping itu, pemahaman solusi alternatif dari pembalut sekali pakai, yaitu pembalut kain hanya sebesar $30 \%$ pada saat sebelum sosialisasi. Hal ini membuktikan bahwa dominan peserta sangat kurang pengetahuannya mengenai adanya pembalut kain sebagai produk substitusi dari pembalut sekali pakai. Rinaldi (2020) memaparkan bahwa sebenarnya terdapat beberapa pengganti pembalut sekali pakai, yaitu menstrual cup, tampon, dan pembalut kain (reusable menstrual pad). Pemateri menjelaskan bahwa di antara berbagai jenis pembalut 
kain tersebut, pembalut kain merupakan jenis pembalut yang paling aman. Menstrual cup merupakan alat modern yang digunakan untuk menampung darah menstruasi. Namun, menstrual cup terbuat dari bahan yang tidak ramah lingkungan, meskipun menstrual cup dapat menghemat pengeluaran. Berkebalikan dengan menstrual cup, tampon justru lebih cenderung bersifat konvensional. Sebagian masyarakat tidak minat terhadap tampon karena dirasa kurang nyaman dalam penggunaannya. Oleh karena itu, para peserta diberikan edukasi bahwa pembalut kain merupakan solusi alternatif yang paling aman.

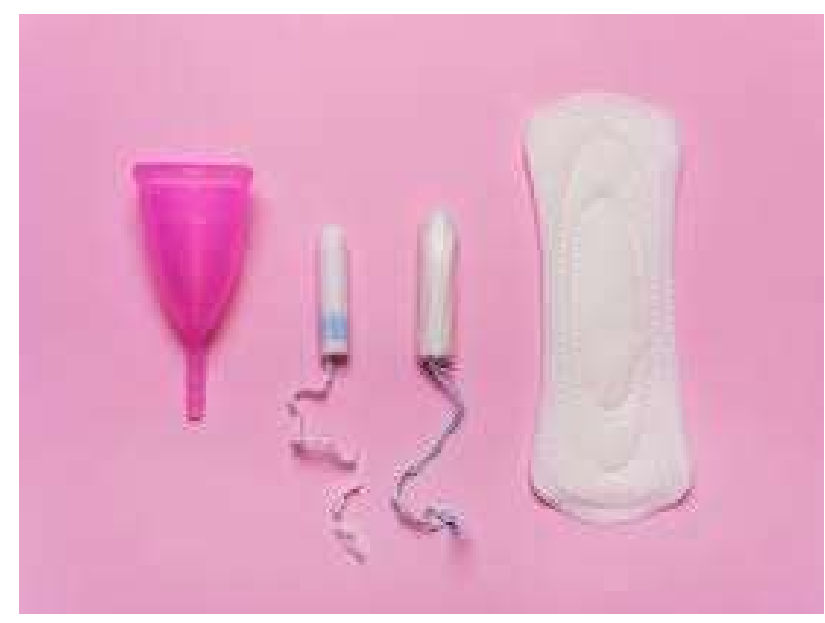

Gambar 4. Menstrual Cup, Tampon, Pembalut Sekali Pakai

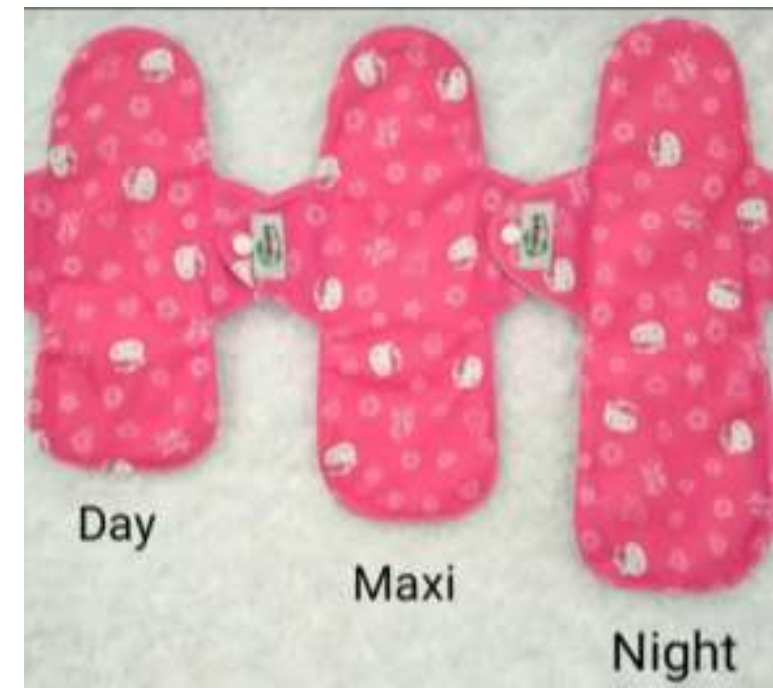

Gambar 5. Pembalut Kain

Kondisi ini relevan dengan hasil observasi terhadap indikator lain, yaitu hanya sebesar $40 \%$ peserta yang telah mengetahui perbedaan pembalut sekali pakai dan pembalut kain. Selain itu, banyak yang beranggapan pembalut sekali pakai lebih hemat dan efisien. Namun kenyataannya yaitu pembalut kain lebih hemat, efisien, dan aman. 
Berikut perbandingan pembalut sekali pakai dan pembalut kain dari segi harga (dalam kurun waktu 2 tahun), yaitu sebagai berikut.

$>$ Pembalut sekali pakai:

Rp. 16.000 x 24 bulan= Rp. 384.000

$>$ Pembalut kain

isi $6=80.000$

Rp. $80.000 \times 3$ box $=$ Rp. 240.000

$>$ Selisih

Pembalut Sekali Pakai - Pembalut Kain

Rp. 384.000 - Rp $240.000=$ Rp. 144.000

Dari hasil tersebut terlihat menggunakan pembalut kain lebih hemat

Rp. 144.000 dari pada pembalut sekali pakai.

Seusai sosialisasi berlangsung, para peserta antusias memberikan pertanyaan. Mayoritas pertanyaan fokus pada cara pencucian pembalut kain agar awet. Di samping itu ada beberapa peserta yang menanyakan terkait batas kewajaran dalam masa menstruasi sebagai indikasi tidak adanya permasalahan organ reproduksi. Setiap pertanyaan yang diajukan telah dijawab dengan baik dan lengkap. Dalam pelaksanaan kegiatan pengabdian masyarakat ini, tidak ditemukan kendala yang berarti. Hal ini dikarenakan sosialisasi ini benar-benar merupakan kebutuhan atau permasalahan mitra, sehingga para peserta memiliki antusiasme yang tinggi. Selain itu, peserta pun mudah memahami materi yang disampaikan.

\section{Kesimpulan}

Secara keseluruhan, pelaksanaan pengabdian masyarakat yang dilaksanakan di Dusun Sentolo Lor, Kecamatan Sentolo, Kabupaten Kulon Progo, Propinsi Daerah Istimewa Yogyakarta dengan target atau sasaran pengabdian masyarakat yaitu ibu-ibu posyandu Dusun Sentolo Lor, telah berjalan dengan amat baik dan lancar. Keberhasilan pelatihan dan sosialisasi yang telah dilakukan dibuktikan dengan hasil pencapaian target luaran pasca pelatihan yang mengindikasikan adanya peningkatan yang sangat signifikan untuk setiap sesi, yaitu sosialisasi dan pelatihan serta setiap indikator dalam setiap sesi. Hal ini telah membuktikan bahwa peserta secara keseluruhan dapat menyerap dan memahami setiap ilmu dan wawasan yang diberikan. Selain itu, hal tersebut juga membuktikan bahwa pengabdi berhasil dalam mentransferkan ilmu yang dimiliki kepada peserta dengan baik, sehingga materi sosialisasi dapat dengan mudah diterima, dipahami, dan diingat oleh setiap peserta. 

Oktober, 2021

\section{Ucapan Terimakasih}

Tim pengabdi mengucapkan terima kasih kepada segenap pengurus wilayah dan para warga Dusun Sentolo Lor, Kecamatan Sentolo, Kabupaten Kulon Progo, Propinsi Daerah Istimewa Yogyakarta, yang telah menyambut kami dengan sangat baik mulai dari tahap persiapan hingga pelaporan. Kegiatan pengabdian masyarakat ini tidak akan berjalan lancar tanpa partisipasi mitra yang telah berkenan menerima dan berkeinginan untuk menghadiri program pemberdayaan masyarakat yang dilaksanakan.

\section{Daftar Pustaka}

Ardiyanti, \& Pramitasari, R. (2019). Ecoliteracy Penggunaan Pembalut Wanita Ramah Lingkungan Kelompok PKK Dusun Panggang, Argomulyo, Sedayu. Seminar Hasil Pengabdian Masyarakat, November, 73-78.

Ariyanti, R., Preharsini, I. A., \& Sipolio, B. V. (2020). Edukasi Kesehatan Dalam Upaya Pencegahan dan Pengendalian Penyakit Hipertensi Pada Lansia. To Maega: Jurnal Pengabdian Masyarakat, 3(2), 74-82. https://doi.org/10.35914/tomaega.v3i2.369

Hasan, A. (2006). Dampak penggunaan klorin. J. Tek. Lingk. P3TL-BPPT, 7(1), 90-96.

http://ejurnal.bppt.go.id/ejurnal2011/index.php/JTL/article/view/456/472

Julina. (2012). Analisis Perilaku Konsumen Perempuan Terhadap Kesehatan Reproduksi Dan Perilaku Penggunaan Pembalut. Marwah: Jurnal Perempuan, Agama Dan Jender, 11(1). https://doi.org/10.24014/marwah.v11i1.498

Karout, N. (2015). Knowledge and beliefs regarding menstruation among Saudi nursing students. Journal of Nursing Education and Practice, 6(1), 23-30. https://doi.org/10.5430/jnep.v6n1p23

Nasution, S., Naria, E., \& Marsaulina, I. (2012). Analisa kandungan klorin (Cl2) pada beberapa merek pembalut wanita yang beredar di pusat perbelanjaan di kota medan. 39(472), 566-571.

Nur, A., Valensia, Y., \& A Lobo, M. Y. (2021). Pelatihan Pengolahan Pangan Lokal Sumber Protein Untuk Meningkatkan Status Gizi Balita Di Kampung Nelayan Oesapa Kupang. To Maega: Jurnal Pengabdian Masyarakat, 4(2), 170-178. https://doi.org/10.35914/tomaega.v4i2.742

Phonna, R., Diba, F., Yuswardi, \& Maulina. (2018). Upaya Menjaga Kebersihan Saat Menstruasi Pada Remaja Putri. Idea Nursing Journal, 9(2), 14-20.

Pristya, T. Y. R., \& Amalia, R. (2021). Edukasi Dengan Media Leaflet Dalam Upaya Peningkatan Pengetahuan Ibu Tentang Pembalut Kain. Jurnal Bakti Masyarakat Indonesia, 3(2), 339-345. https://doi.org/10.24912/jbmi.v3i2.9428

Ristanti, A. D., \& Masita, E. D. (2021). Peran Kader dalam Mendorong Pemberian ASI di Masa Pandemi Covid-19. To Maega : Jurnal Pengabdian Masyarakat, 4(1), 47-54. https://doi.org/10.35914/tomaega.v4i1.474

Rosyida, D. A. C., Hidayatunnikmah, N., \& Marliandiani, Y. (2021). Pendampingan Penerapan Pembuatan PMT (Pemberian Makanan Tambahan) license (https://creativecommons.org/licenses/by-sa/4.0/). 
[ 330 ] Anindita Imam Basri, dkk / To Maega : Jurnal Pengabdian Masyarakat, Vol.4; No.3; Oktober, 2021

untuk Ibu dan Balita Guna Meningkatkan Kesehatan Ibu dan Anak. To Maega: Jurnal Pengabdian Masyarakat, 4(2), 187-195. https://doi.org/10.35914/tomaega.v4i2.744

Siahaan, S. C. P., Yuwono, N., Susanto, \& Pristiwanto, N. (2021). Pendidikan Dini Prinsip Edukasi Kesehatan Gizi Seimbang melalui metode Kids Play and Care. To Maega: Jurnal Pengabdian Masyarakat, 4(2), 179-186. https://doi.org/10.35914/tomaega.v4i2.743

Susanti, E. M., \& Wijaya, P. S. (2018). Perbedaan Penggunaan Pembalut Dan Pantyliner Jenis Biasa, Herbal, Dan Kain Dengan Kejadian Keputihan. Indonesia Jurnal Kebidanan, 2(1), 31. https://doi.org/10.26751/ijb.v2i1.427

Zamani, I. S., Husna, L. A., \& Yulianingtyas, A. (2012). Pembalut Wanita Ramah Lingkungan Dan Beretika. Prosiding Elektronik (e-Proceedings) PIMNAS, $1-5$. 